\title{
DETERMINATION OF HEAVY METALS AND LEAD- STRONTIUM ISOTOPE CHARACTERIZATION FROM MERLOT SOIL SAMPLES, DEALU BUJORULUI VINEYARD
}

\author{
FLORIN DUMITRU BORA ${ }^{\mathrm{a}}$, ALINA DONICI ${ }^{\mathrm{a}}$, ANAMARIA CALUGAR $^{\mathrm{b}}$, \\ IOAN VALENTIN PETRESCU MAG ${ }^{c}$, EMESE GÁL ${ }^{d}$, \\ CLAUDIU IOAN BUNEA ${ }^{\mathrm{b}}$
}

\begin{abstract}
Contamination of vineyard soils with heavy-metals has been a worldwide concern, determination of these elements it is important for the wine industry. The aim of this research was to determine the concentration of different heavy metals ( $\mathrm{Cd}, \mathrm{Pb}, \mathrm{U}, \mathrm{Hg}, \mathrm{As}, \mathrm{Sr}, \mathrm{Co}, \mathrm{Cu}, \mathrm{Ni}$ and $\mathrm{Cr}$ ) from vineyard soil on different depths in an area of vineyard cultivation from Dealu Bujorului Galati County. In order to highlight the combination of different sources, natural or anthropogenic of heavy metals the isotopic ratios for ${ }^{206} \mathrm{~Pb} /{ }^{207} \mathrm{~Pb}$, ${ }^{208} \mathrm{~Pb} /{ }^{206} \mathrm{~Pb},{ }^{206} \mathrm{~Pb} /{ }^{207} \mathrm{~Pb}$ and ${ }^{87} \mathrm{Sr} /{ }^{86} \mathrm{Sr}$ from soil were established. The highest concentrations for heavy metals were recorded on the surface, with increasing depth of the soil these concentrations decrease. Regarding of $\mathrm{Pb}$ sources (lithogenic or anthropogenic), the average ${ }^{206} \mathrm{~Pb} /{ }^{207} \mathrm{~Pb},{ }^{208} \mathrm{~Pb} /{ }^{206} \mathrm{~Pb}$ and ${ }^{206} \mathrm{~Pb} /{ }^{204} \mathrm{~Pb}$ ratios in soil profile increase horizons followed the order: 1.13526 $\left(0-10 \mathrm{~cm}{ }^{206} \mathrm{~Pb} /{ }^{207} \mathrm{~Pb}\right)>1.13427\left(10-20 \mathrm{~cm}{ }^{206} \mathrm{~Pb} /{ }^{207} \mathrm{~Pb}\right) ; 2.12626(10-20 \mathrm{~cm}$ $\left.{ }^{208} \mathrm{~Pb} /{ }^{206} \mathrm{~Pb}\right)>2.12472\left(10-20 \mathrm{~cm}{ }^{208} \mathrm{~Pb} /{ }^{206} \mathrm{~Pb}\right)$ and $17.36201(10-20 \mathrm{~cm}$ $\left.{ }^{206} \mathrm{~Pb} /{ }^{204} \mathrm{~Pb}\right)>17.36128\left(0-10 \mathrm{~cm}{ }^{206} \mathrm{~Pb} /{ }^{204} \mathrm{~Pb}\right)$. Statistically, in the case of ${ }^{206} \mathrm{~Pb} /{ }^{207} \mathrm{~Pb}$ and ${ }^{208} \mathrm{~Pb} /{ }^{206} \mathrm{~Pb}$ there are very significant differences between the analyzed variants while ${ }^{206} \mathrm{~Pb} /{ }^{204} \mathrm{~Pb}$ does not show any differences with in terms of distribution on the depth of the soil profile. Our results confirm that the
\end{abstract}

a Research Station for Viticulture and Enology Targu Bujor, 65 G-ral Eremia Grigorescu, RO805200, Galați Country Romania

b University of Agricultural Sciences and Veterinary Medicine, Department of Horticulture and Landscaping, 3-5 Mănăştur Street, RO-400372 Cluj-Napoca, Romania

c University of Agricultural Sciences and Veterinary Medicine, Department of Agriculture, 3-5 Mănăştur Street, RO-400372 Cluj-Napoca, Romania

d Babeş-Bolyai University, Faculty of Chemistry and Chemical Engineering, 11 Arany Janos str., RO-400028, Cluj-Napoca, Romania

*Corresponding author boraflorindumitru@gmail.com 
${ }^{207} \mathrm{~Pb} /{ }^{206} \mathrm{~Pb},{ }^{208} \mathrm{~Pb} /{ }^{206} \mathrm{~Pb},{ }^{204} \mathrm{~Pb} /{ }^{206} \mathrm{~Pb}$ and ${ }^{87} \mathrm{Sr} /{ }^{86} \mathrm{Sr}$ isotope ratio can be used to track the geographical origin of wine, discriminate between wine production regions, and be used to characterize wine terroirs for forensic purpose.

Keywords: heavy metals, soil profile, ${ }^{207} \mathrm{~Pb} /{ }^{006} \mathrm{~Pb},{ }^{208} \mathrm{~Pb} /{ }^{206} \mathrm{~Pb},{ }^{204} \mathrm{~Pb} /{ }^{206} \mathrm{~Pb}$, ${ }^{87} \mathrm{Sr}{ }^{\beta 6}$ Srisotope ratio.

\section{INTRODUCTION}

The soil conservation is an important and fundamental factor for sustainable development and preservation, biodiversity and balance of ecosystems. The main sources of different elements in soil are natural background (elements derived from parent rocks) and anthropogenic, which include agrochemicals, amendments, mineral fertilizer, irrigation, sewage sludge and also, the industrial wastes [1,2]. Nevertheless, the concentration, the distribution and the bioavailability of chemical elements in the environment are influenced mainly by the climatic conditions, soil type, topography, geology, and erosive process [3, 4].

Between anthropic activities, agriculture is the main pollutant and contaminant of soil. Viticulture is an intensive practice, so the phytopharmaceuticals and chemical fertilizers are the main source of elemental pollution [5]. In vineyard areas, the use of fungicide based on $\mathrm{Cu}$ in their composition pollute the soil by accumulation in high concentrations in worldwide grapevine areas [6-9]. Vines and other plants have the capacity to tolerate $\mathrm{Cu}$ in excess. Plants differ in terms of their capacity to accumulate heavy metals depending on genotype, on the soil conditions and on the microorganism associated to the soil, which play the role of pollutants absorbers [10]. The most of the cooper and other applied chemical tends to remain on the surface of soils [11]. Some European countries have banned the use or restricted the amount of copper-based fungicides, in response to environmental concerns over the accumulation of copper in agricultural soils and the potential impact on soil ecology [12].

Lead is an element found in the Earth's crust and soil and may be taken by plants (some species absorbing more than others, especially in certain parts) and grazing animals. The lead is evacuated in the atmosphere by different sources and can get directly into organism within the inspired air, or indirectly, after the depositing on the surface or soil, then water and food [13]. Nickel is an element found in soil and is highly dependent on the content of the parent rock material and climatic conditions, meaning that, in 
soil of arid and semiarid regions, its amounts are higher [14]. The total content of $\mathrm{Ni}$ showed significant positive correlation with the organic matter from soil surface $(0-20 \mathrm{~cm}$ depth) which indicate that the organic matter on the first layer of the cultivated soil contribute to Ni retention in the soil [9]. Nickel may be removed by some cultures or by leaching to deeper layer in the soil profile and this could justify the reduction of this element in some areas given its high mobility $[15,16]$. Arsenic is a metalloid well-known for its toxicity and it is found in the environment from natural and anthropogenic sources (represented by mining, the use of pesticides in agriculture, industrial and municipal wastes discharging, burning of fossil fuels) [17].

Evaluation of natural abundance isotope ratios provides information on plant type or animal diet (carbon ratios) and geographical origin (lead, strontium, deuterium and oxygen isotopic ratios) [18]. Strontium is found in nature as three abundant isotopes: ${ }^{86} \mathrm{Sr},{ }^{87} \mathrm{Sr},{ }^{88} \mathrm{Sr}$ and ${ }^{84} \mathrm{Sr}$ as less abundant isotope [19-20]. Since the content of ${ }^{87} \mathrm{Sr}$ in soil varies with geological age and geographical location, the ${ }^{87} \mathrm{Sr} /{ }^{86} \mathrm{Sr}$ isotopic ratio can be used as a tracer for determining the geographical origin of grapes and wine [21]. Lead is found in nature as four abundant isotopes: ${ }^{206} \mathrm{~Pb},{ }^{207} \mathrm{~Pb},{ }^{208} \mathrm{~Pb}$ and ${ }^{204} \mathrm{~Pb}$ as less abundant isotope [22]. The $\mathrm{Pb}$ isotope of ore deposits and anthropogenic sources has their distinct isotopic ratios or signatures [23]. The $\mathrm{Pb}$ isotope ratio did not change in industrial or environmental processing and it's retained its characteristic ratio from source ore [24]. Each geologic substratum of vineyards is liable to heave its own $\mathrm{Sr}$ isotope composition, which can potentially represent a fingerprint to trace the wine production provenance [25]. The use of ${ }^{87} \mathrm{Sr} /{ }^{86} \mathrm{Sr}$ in tracking wine regional provenances was among the most pioneering application of isotope geology to other sciences [26]. In most of the cases, however, the analytical uncertainty observed in $\mathrm{Sr}$ isotopes analyses of wines from literature is larger than most of the soil/rock isotopic variability, giving strong difficulties in matching data of wines with those from geologic substrata of the vineyards. Recently, high precision analytical method for determining ${ }^{87} \mathrm{Sr} /{ }^{86} \mathrm{Sr}$ has been provide enabling then direct comparison between data on wines with those of the pedological and geological substrata $[27,28]$. Long lived isotope ratios of heavy metals of geological interest, such as ${ }^{87} \mathrm{Sr} /{ }^{86} \mathrm{Sr},{ }^{206} \mathrm{~Pb} /{ }^{204} \mathrm{~Pb}$, ${ }^{207} \mathrm{~Pb} / 204 \mathrm{~Pb},{ }^{208} \mathrm{~Pb} /{ }^{204} \mathrm{~Pb}$, have in the last decades gained importance in tackling the issues of geographical food traceability as well as in solving issues related with archaeological, environmental, medical and also forensic sciences [29].

The purpose of this study was to determine the elemental composition ( $\mathrm{Cd}, \mathrm{Pb}, \mathrm{U}, \mathrm{Hg}, \mathrm{As}, \mathrm{Sr}, \mathrm{Co}, \mathrm{Cu}, \mathrm{Ni}$ and $\mathrm{Cr}$ ) from vineyard soil, on different depths $(0-120 \mathrm{~cm})$ using the ICP-MS technique (method approved by 
L'Organisation International du Vie et Vin) and also to complete the knowledge of the large-scale distribution of strontium $\left({ }^{87} \mathrm{Sr} /{ }^{86} \mathrm{Sr}\right)$ and lead $\left({ }^{206} \mathrm{~Pb} /{ }^{204} \mathrm{~Pb},{ }^{207} \mathrm{~Pb} /{ }^{204} \mathrm{~Pb},{ }^{208} \mathrm{~Pb} /{ }^{204} \mathrm{~Pb}\right)$ isotope ratios in soil from Dealu Bujorului Vineyard (Galati county).

\section{RESULTS AND DISCUSSION}

\section{Heavy metals content from Merlot soil samples}

In Table 1 are summarized the total contents of $\mathrm{Cd}, \mathrm{Pb}, \mathrm{U}, \mathrm{Hg}, \mathrm{As}, \mathrm{Sr}$, $\mathrm{Co}, \mathrm{Cu}, \mathrm{Ni}$ and $\mathrm{Cr}$ on the depth of the soil profile. The mean contents of $\mathrm{Cd}$ and $\mathrm{Pb}$ were $0.33 \pm 0.05 \mathrm{mg} / \mathrm{kg}$ and $6.20 \pm 0.57 \mathrm{mg} / \mathrm{kg}$, in case of $\mathrm{Cd}$ the lowest concentrations were recorded in the surface of the soil profile $[0.19 \pm 0.02 \mathrm{mg} / \mathrm{kg}(10-20 \mathrm{~cm})]$, while the highest concentration was recorded on the depth of the soil profile $[0.61 \pm 0.05 \mathrm{mg} / \mathrm{kg}(90-100 \mathrm{~cm})] . \mathrm{Pb}$ content in sol ranged from $[10.46 \pm 1.28 \mathrm{mg} / \mathrm{kg}(10-20 \mathrm{~cm})]$ and $[2.61 \pm 0.73 \mathrm{mg} / \mathrm{kg}(110-$ $120 \mathrm{~cm})]$, the highest concentration was recorded on the surface of the soil profile. The results agree with other scientific papers [30] $0.30 \mathrm{mg} / \mathrm{kg}(\mathrm{Cd})$, $11.50 \mathrm{mg} / \mathrm{kg}(\mathrm{Pb})$; [31] $0.18 \mathrm{mg} / \mathrm{kg}(\mathrm{Cd})$ and significantly lower than those obtained by some authors [32] $7.38 \mathrm{mg} / \mathrm{kg}(\mathrm{Cd}), 132.30 \mathrm{mg} / \mathrm{kg}(\mathrm{Pb})$ and [31] $36.00 \mathrm{mg} / \mathrm{kg}(\mathrm{Pb})$. The $\mathrm{U}$ concentration from soil was between $[0.51 \pm 0.10$ $\mathrm{mg} / \mathrm{kg}(0-10 \mathrm{~cm})]$ and $[0.25 \pm 0.10 \mathrm{mg} / \mathrm{kg}(110-120 \mathrm{~cm})]$ with an average of $0.35 \pm 0.06 \mathrm{mg} / \mathrm{kg}$. Regarding the distribution of $U$ concentration on the depth of the soil profile, it can be observed that with increase of the depth the $U$ concentration from soil decreases, as in the case of $\mathrm{Pb}$. The results agree with Moragues-Quiroga et al. [33] $0.03 \mathrm{mg} / \mathrm{kg}(\mathrm{U})$; and significantly lower than those obtained by Saat et al. [34] $2.21 \mathrm{mg} / \mathrm{kg}(U)$.

The content of $\mathrm{Hg}$, As Sr and Co found in Dealu Bujorului Vineyard agreed with literature data [33, 35-37]. The average values of these metals $0.076 \pm 0.012 \mathrm{mg} / \mathrm{kg}(\mathrm{Hg}), 1.31 \pm 0.11 \mathrm{mg} / \mathrm{kg}(\mathrm{As}), 34.44 \pm 1.62 \mathrm{mg} / \mathrm{kg}(\mathrm{Sr})$ and $3.45 \pm 0.25 \mathrm{mg} / \mathrm{kg}$ (Co) do not indicate soil pollution in Dealu Bujorului vineyard (Table 1).

In terms of $\mathrm{Ni}$ and $\mathrm{Cr}$ the highest concentration was recorded in the surface of the soil profile for both metals, Ni $[9.17 \pm 0.99 \mathrm{mg} / \mathrm{kg}(0-10 \mathrm{~cm})$; $8.18 \pm 1.00 \mathrm{mg} / \mathrm{kg}(10-20 \mathrm{~cm})]$ and $\mathrm{Cr}[13.80 \pm 1.33 \mathrm{mg} / \mathrm{kg}(30-40 \mathrm{~cm}) ; 13.08 \pm 0.83$ $\mathrm{mg} / \mathrm{kg}(20-30 \mathrm{~cm})]$ with an average value of $5.61 \pm 0.23 \mathrm{mg} / \mathrm{kg}(\mathrm{Ni})$ and $10.81 \pm 0.72 \mathrm{mg} / \mathrm{kg}(\mathrm{Cr})$ (Table 1). The results agree with literature data [30-37].

Concerning $\mathrm{Cu}$ concentration in soil, at the surface of the soil profile were recorded the highest concentration $[546.01 \pm 9.15 \mathrm{mg} / \mathrm{kg}(0-10 \mathrm{~cm})$; $521.37 \pm 4.59 \mathrm{mg} / \mathrm{kg}(10-20 \mathrm{~cm})]$ with an average value of $371.25 \pm 2.01 \mathrm{mg} / \mathrm{kg}$, 
these concentrations from far exceed the maximum allowed by the legislation $(20 \mathrm{mg} / \mathrm{kg}$ ). The data demonstrate strong pollution of vineyard soil by copper. Copper concentrations in the topsoil of Dealu Bujorului vineyard was between the values of $546.01 \pm 9.15 \mathrm{mg} / \mathrm{kg}(0-10 \mathrm{~cm})$ and $120.59 \pm 1.15 \mathrm{mg} / \mathrm{kg}(80-90 \mathrm{~cm})$ with an average value of $356.03 \pm 4.36 \mathrm{mg} / \mathrm{kg}$. The copper enrichment in different vineyard soil types reflects the period of copper-based pesticide application [39]. We consider the climate and application of elevated volumes of fungicide as the circumstantial factor for the high copper contamination in vineyards soil. Copper concentration in soil is significantly lower than the maximum value reported in literature $(1500 \mathrm{mg} / \mathrm{kg})$ [40]. Regarding the distribution of copper concentration on the depth of the soil profile, it can be observed that with increase of the depth the copper concentration from soil decreases. We assume that total copper distribution between vine lines mainly depends on certain technical operations, such as implemented spraying technical operations, foliage removing from midway zones or simply foliage and other organic debris redistribution in horizontal directions by winds, machine wheels, animals and/or humans [39].

The copper sulphate actually are used in all wine counties and also in Bordeaux, according to Mirlean et al. [39] mixture preparation contains: $\mathrm{Zn}$ $1309 \mathrm{mg} / \mathrm{kg}, \mathrm{Pb} 95 \mathrm{mg} / \mathrm{kg}, \mathrm{Cr} 19 \mathrm{mg} / \mathrm{kg} \mathrm{Ni} 10 \mathrm{mg} / \mathrm{kg}$ and Cd $1.4 \mathrm{mg} / \mathrm{kg}$. Therefore, we considered that copper-based pesticide is the principal source of established soil enrichment by heavy metals. Similar conclusions have reached also some authors in Serbia [32], Brasil [39], Italy [41], Romania [42], France [43] and Spain [44]. The results agree with Alagić et al. [32] $315.00 \mathrm{mg} / \mathrm{kg}(\mathrm{Cu})$, Couto et al. [45] $602.23 \mathrm{mg} / \mathrm{kg}(\mathrm{Cu})$, Romić et al. [46] $586 \mathrm{mg} / \mathrm{kg}(\mathrm{Cu})$, Chaignon et al. [47] $398586 \mathrm{mg} / \mathrm{kg}(\mathrm{Cu})$ and significantly higher than those obtained by Rusjan et al. [48] $88.00 \mathrm{mg} / \mathrm{kg}(\mathrm{Cu})$.

Concerning factor which influences the distribution of metals on the soil profile, it can be seen as the depth factor had influenced very significant distribution $\mathrm{Cd}, \mathrm{Pb}, \mathrm{U}, \mathrm{As}, \mathrm{Sr}, \mathrm{Co}, \mathrm{Cu}, \mathrm{Ni}$ and $\mathrm{Cr}$, in case of $\mathrm{Hg}$ distribution on the soil profile depth factor had a lesser influence (Table 1).

Reporting the obtained results [Cd average $0.33 \pm 0.05 \mathrm{mg} / \mathrm{kg}(1 \mathrm{mg} / \mathrm{kg}$ M.A.L = (maximum limit allowed); Pb average $5.82 \pm 0.75 \mathrm{mg} / \mathrm{kg}(20 \mathrm{mg} / \mathrm{kg}$ M.A.L); $\mathrm{Hg}$ average $0.076 \pm 0.012 \mathrm{mg} / \mathrm{kg}(0.1 \mathrm{mg} / \mathrm{kg}$ M.A.L); As average $1.31 \pm 0.11 \mathrm{mg} / \mathrm{kg}$ (1 mg/kg M.A.L); Co average $3.45 \pm 0.25 \mathrm{mg} / \mathrm{kg}$ (15 mg/kg M.A.L); Ni average $5.61 \pm 0.23 \mathrm{mg} / \mathrm{kg}(1 \mathrm{mg} / \mathrm{kg}$ M.A.L) and $\mathrm{Cr}$ average $10.81 \pm 0.72 \mathrm{mg} / \mathrm{kg}(30 \mathrm{mg} / \mathrm{kg}$ M.A.L)] to national and international legislation we can say that the soil from Dealu Bujorului vineyard falls within the limits set by the law, except the $\mathrm{Cu}$ average $356.03 \pm 4.36 \mathrm{mg} / \mathrm{kg}$ concentration which exceeds this limit $(20 \mathrm{mg} / \mathrm{kg})$ (Table 1). 
F. D. BORA, A. DONICI, A. CALUGAR, I. V. PETRESCU MAG, E. GÁL, C. I. BUNEA

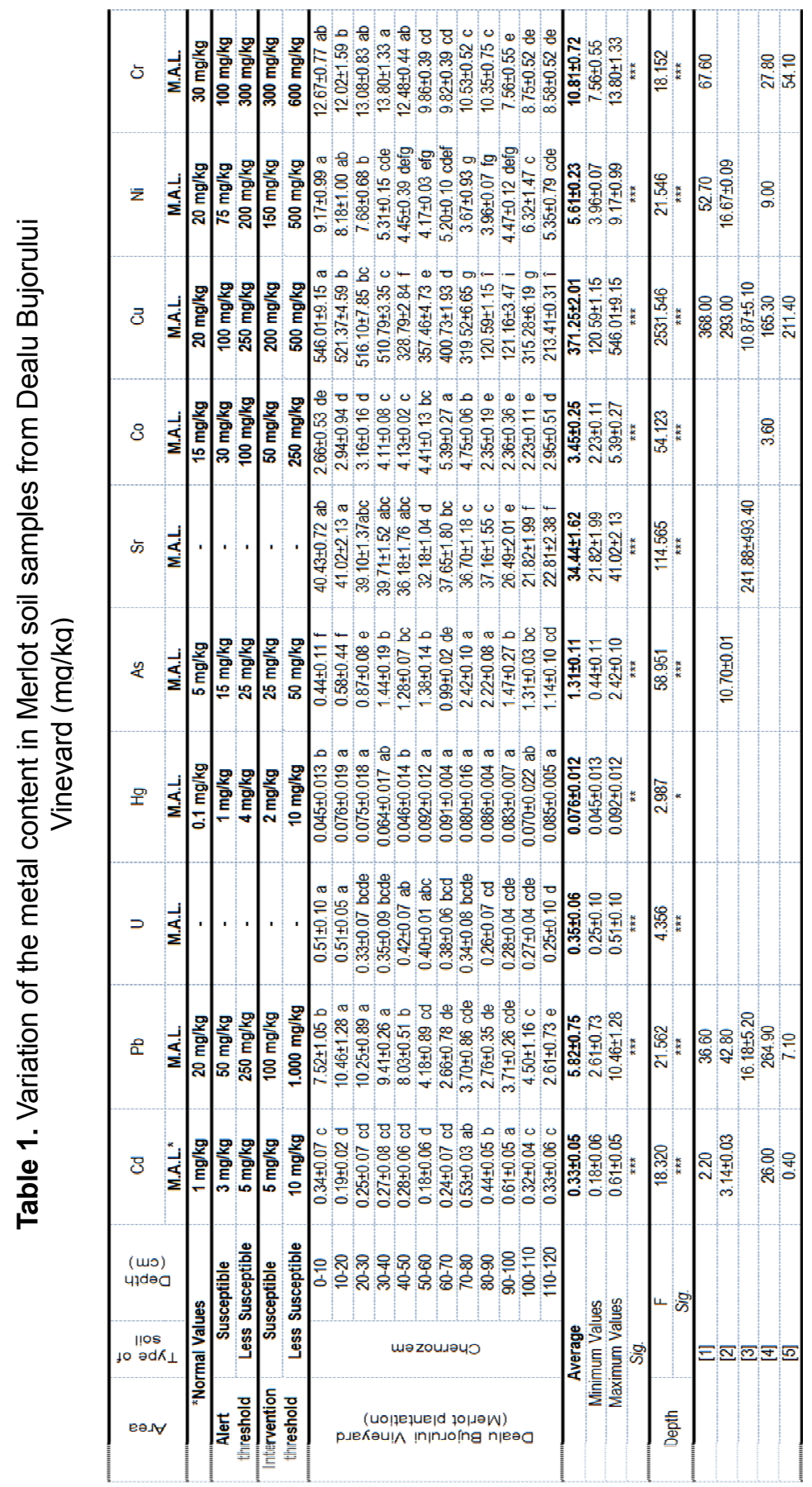

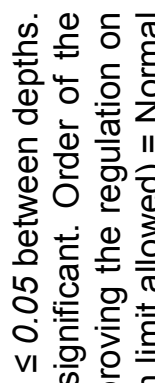

․ㅡ을 ह

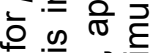

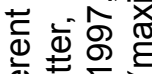

(屯)

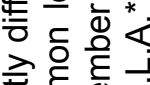

ॠॄ है

응 응 성

음

항 윰

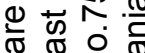

⿻ 丨

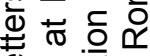

(1) ح웡

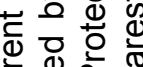

选造远

응 岳 लेँ है

II की 들을

ᄃ증 을 긍

을 인 뜸

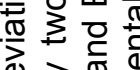

đั

읗 ㄷํㅇ 은

일 오 잉

तु $\sum_{0}$ का ब

क बे

(1)

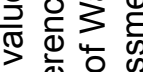

ब.

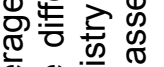

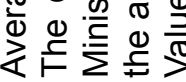




\section{${ }^{206} \mathrm{~Pb} /{ }^{207} \mathrm{~Pb},{ }^{208} \mathrm{~Pb} /{ }^{206} \mathrm{~Pb},{ }^{206} \mathrm{~Pb} /{ }^{204} \mathrm{~Pb},{ }^{87} \mathrm{Sr} /{ }^{86} \mathrm{Sr}$, isotope ratio from Merlot soil samples}

The $\mathrm{Pb}$ isotope ratio for the selected soil (Table 2 ) varies in range between 1.13142-1.14205 $\left({ }^{206} \mathrm{~Pb} /{ }^{207} \mathrm{~Pb}\right), 2.12065-2.14153\left({ }^{208} \mathrm{~Pb} /{ }^{206} \mathrm{~Pb}\right)$ and 17.29604-17.42010 $\left({ }^{206} \mathrm{~Pb} / 204 \mathrm{~Pb}\right)$ with average $1.13418 \quad\left({ }^{206} \mathrm{~Pb} /{ }^{207} \mathrm{~Pb}\right)$, $2.12906\left({ }^{208} \mathrm{~Pb} /{ }^{206} \mathrm{~Pb}\right)$ and $17.36398\left({ }^{206} \mathrm{~Pb} /{ }^{204} \mathrm{~Pb}\right)$. The wide range of isotope ratio obtained suggest that $\mathrm{Pb}$ content in the soil is a product of the combination of different sources and not from a sole origin, natural or anthropogenic, and that it has also been accumulating over time since the massive use of $\mathrm{Pb}$ in fuel, pain [49]. The ${ }^{206} \mathrm{~Pb} /{ }^{207} \mathrm{~Pb}$ ratio is most commonly used in environmental studies because it can be determined precisely, and the abundances of these isotopes are relatively important [50]. The isotope ration ${ }^{206} \mathrm{~Pb} /{ }^{207} \mathrm{~Pb}$ revealed a different behaviour between soil profiles at each sampling site.

Regarding ${ }^{206} \mathrm{~Pb} /{ }^{207} \mathrm{~Pb}$ isotope ration based on analyses it can be concluded that the vineyard soil from Dealu Bujorului with an average values of $1.13418{ }^{206} \mathrm{~Pb} /{ }^{207} \mathrm{~Pb}$ come from automobile emissions (if ${ }^{206} \mathrm{~Pb} /{ }^{207} \mathrm{~Pb}=1.1000-1.1400$ [automobile emissions]) [51]. The values of ${ }^{208} \mathrm{~Pb} /{ }^{206} \mathrm{~Pb}$ and ${ }^{206} \mathrm{~Pb} / 204 \mathrm{~Pb}$ isotope ratio are between the ranges from 2.12065 to $2.14153\left({ }^{208} \mathrm{~Pb} / 206 \mathrm{~Pb}\right)$ and 17.29604 to $17.42010\left({ }^{206} \mathrm{~Pb} / 204 \mathrm{~Pb}\right)$ with an average values of $2.12906\left({ }^{208} \mathrm{~Pb} /{ }^{206} \mathrm{~Pb}\right)$ and $17.36398\left({ }^{206} \mathrm{~Pb} /{ }^{204} \mathrm{~Pb}\right)$. The highest values of ${ }^{208} \mathrm{~Pb} /{ }^{206} \mathrm{~Pb}$ and ${ }^{206} \mathrm{~Pb} / 204 \mathrm{~Pb}$ isotope ratio were registered on the depth of the soil profile from $70-80 \mathrm{~cm}\left[2.14153\left({ }^{208} \mathrm{~Pb} / 206 \mathrm{~Pb}\right)\right]$ followed by $80-90 \mathrm{~cm}\left[2.13417\left({ }^{208} \mathrm{~Pb} /{ }^{206} \mathrm{~Pb}\right)\right]$ and values recorded at 50-60 cm [17.42010 $\left.\left({ }^{206} \mathrm{~Pb} / 204 \mathrm{~Pb}\right)\right]$ followed by $90-100 \mathrm{~cm}\left[17.41431\left({ }^{206} \mathrm{~Pb} / 204 \mathrm{~Pb}\right)\right]$ and $110-120 \mathrm{~cm}$ [17.39252 $\left.\left({ }^{206} \mathrm{~Pb} /{ }^{204} \mathrm{~Pb}\right)\right]$. The lowest values of ${ }^{08} \mathrm{~Pb} / 206 \mathrm{~Pb}$ and ${ }^{206} \mathrm{~Pb} / 204 \mathrm{~Pb}$ isotope ratio were recorded also on the depth of the soil profile $30-40 \mathrm{~cm}$ [2.21065 $\left.\left({ }^{208} \mathrm{~Pb} / 206 \mathrm{~Pb}\right)\right]$ followed by $110-120 \mathrm{~cm}\left[2.12311\left({ }^{208} \mathrm{~Pb} / 206 \mathrm{~Pb}\right)\right], 10-20$ $\mathrm{cm}\left[2.12472\left({ }^{208} \mathrm{~Pb} /{ }^{206} \mathrm{~Pb}\right)\right], 60-70 \mathrm{~cm}$ [2.12443 $\left.\left({ }^{208} \mathrm{~Pb} /{ }^{206} \mathrm{~Pb}\right)\right], 90-100 \mathrm{~cm}$ [2.12512 $\left.\left({ }^{208} \mathrm{~Pb} /{ }^{206} \mathrm{~Pb}\right)\right], 100-110$ [2.12457 $\left.\left({ }^{208} \mathrm{~Pb} /{ }^{206} \mathrm{~Pb}\right)\right]$.

Regardless of $\mathrm{Pb}$ sources (lithogenic or anthropogenic), the average ${ }^{206} \mathrm{~Pb} /{ }^{207} \mathrm{~Pb},{ }^{208} \mathrm{~Pb} /{ }^{206} \mathrm{~Pb}$ and ${ }^{206} \mathrm{~Pb} / 204 \mathrm{~Pb}$ ration in soil profile horizons followed the order: $1.13526\left(0-10 \mathrm{~cm}{ }^{206} \mathrm{~Pb} / 207 \mathrm{~Pb}\right)>1.13427\left(10-20 \mathrm{~cm}{ }^{206} \mathrm{~Pb} /{ }^{207} \mathrm{~Pb}\right)$; $2.12626\left(10-20 \mathrm{~cm}{ }^{208} \mathrm{~Pb} /{ }^{206} \mathrm{~Pb}\right)>2.12472\left(10-20 \mathrm{~cm}{ }^{208} \mathrm{~Pb} / 206 \mathrm{~Pb}\right)$ and $17.36201\left(10-20 \mathrm{~cm} \quad{ }^{206} \mathrm{~Pb} /{ }^{204} \mathrm{~Pb}\right)>17.36128\left(0-10 \mathrm{~cm} \quad{ }^{206} \mathrm{~Pb} /{ }^{204} \mathrm{~Pb}\right)$. Statistically, in the case of ${ }^{206} \mathrm{~Pb} /{ }^{207} \mathrm{~Pb}$ and ${ }^{208} \mathrm{~Pb} /{ }^{206} \mathrm{~Pb}$ there are very significant differences between the analyzed variants while ${ }^{206} \mathrm{~Pb} / 204 \mathrm{~Pb}$ does not show any differences with in terms of distribution on the depth of the soil profile.

These results demonstrate that $\mathrm{Pb}$ isotopic ratios were derived mainly from weathered parent material, except the ${ }^{206} \mathrm{~Pb} /{ }^{207} \mathrm{~Pb}$ uppermost horizons of soil profiles which come from automobile emissions. The more radiogenic ${ }^{208} \mathrm{~Pb} /{ }^{206} \mathrm{~Pb}$ and ${ }^{206} \mathrm{~Pb} /{ }^{207} \mathrm{~Pb}$ ratio in soil probably reflects the $\mathrm{Pb}$ derived from 
weathered bedrock, and the isotopic composition of $\mathrm{Pb}$ is mostly influenced by the decay of $U$ and Th content in the soil, weathering processes and original rock age, which provide a fingerprint used for different forensic and archeological purposes [52].

Concerning ${ }^{87} \mathrm{Sr} /{ }^{86} \mathrm{Sr}$, isotope ratio the values are between the ranges from 0.72316 to 0.72701 , with an average value of 0.72514 . The highest values were registered on the depth of the soil surface profile $60-70 \mathrm{~cm}$ $(0.72701)$ followed by values recorded at $40-50 \mathrm{~cm}(0.72653)$ and $50-60 \mathrm{~cm}$ (0.72616), the lowest value of ${ }^{87} \mathrm{Sr} /{ }^{86} \mathrm{Sr}$ isotope ratio was registered on the depth of the soil at $70-80 \mathrm{~cm}(0.722316)$ (Table 2). In this case, these are no significant differences between the ${ }^{87} \mathrm{Sr} / 86 \mathrm{Sr}$ isotope ratio. These obtained values of ${ }^{87} \mathrm{Sr} /{ }^{86} \mathrm{Sr}$ isotope ratio can be attributed to a larger proportion of radiogenic ( $\mathrm{K}$ and $\mathrm{Rb}$ rich) mineral due to the weathering of the most weatherable mineral, i.e. Ca-plagioclase, which is promoted by a strong decrease of the soil $\mathrm{pH}$ [53].

\section{CONCLUSIONS}

In this work the heavy metals concentration from Merlot plantation was studied in order to highlight the heavy metals composition of soil. In case of $\mathrm{Cd}(1 \mathrm{mg} / \mathrm{kg}), \mathrm{Pb}(20 \mathrm{mg} / \mathrm{kg}), \mathrm{Hg}(0.1 \mathrm{mg} / \mathrm{kg})$, As (5 mg/L), Co (15 $\mathrm{mg} / \mathrm{kg})$, Ni $(20 \mathrm{mg} / \mathrm{kg})$ and $\mathrm{Cr}(30 \mathrm{mg} / \mathrm{kg})$ metals in analysed soil samples were under Maximum Permissible Limits (MPL). Cu concentration in the soil exceeds the maximum admissible limit $(20 \mathrm{mg} / \mathrm{kg})$ having the average value of $371.25 \mathrm{mg} / \mathrm{kg}$, this value is a common one for vineyards soils.

Regardless of $\mathrm{Pb}$ sources (lithogenic or anthropogenic), the average ${ }^{206} \mathrm{~Pb} / 207 \mathrm{~Pb},{ }^{208} \mathrm{~Pb} /{ }^{206} \mathrm{~Pb}$ and ${ }^{206} \mathrm{~Pb} / 204 \mathrm{~Pb}$ ration in soil profile horizons followed the order: $1.13526\left(0-10 \mathrm{~cm}{ }^{206} \mathrm{~Pb} / 207 \mathrm{~Pb}\right)>1.13427(10-$ $\left.20 \mathrm{~cm}{ }^{206} \mathrm{~Pb} / 207 \mathrm{~Pb}\right) ; 2.12626\left(10-20 \mathrm{~cm}{ }^{208} \mathrm{~Pb} / 206 \mathrm{~Pb}\right)>2.12472(10-20 \mathrm{~cm}$ $\left.{ }^{208} \mathrm{~Pb} / 206 \mathrm{~Pb}\right)$ and $17.36201\left(10-20 \mathrm{~cm}{ }^{206} \mathrm{~Pb} / 204 \mathrm{~Pb}\right)>17.36128(0-10 \mathrm{~cm}$ ${ }^{206} \mathrm{~Pb} / 204 \mathrm{~Pb}$ ). Statistically, in the case of ${ }^{206} \mathrm{~Pb} /{ }^{207} \mathrm{~Pb}$ and ${ }^{208} \mathrm{~Pb} / 206 \mathrm{~Pb}$ there are very significant differences between the analyzed variants while ${ }^{206} \mathrm{~Pb} /{ }^{204} \mathrm{~Pb}$ does not show any differences with in terms of distribution on the depth of the soil profile.

Our results confirm that the ${ }^{207} \mathrm{~Pb} /{ }^{206} \mathrm{~Pb},{ }^{208} \mathrm{~Pb} /{ }^{206} \mathrm{~Pb},{ }^{204} \mathrm{~Pb} /{ }^{206} \mathrm{~Pb}$ and ${ }^{87} \mathrm{Sr} /{ }^{86} \mathrm{Sr}$ isotope ratio can be used to track the geographical origin of wine, discriminate between wine production regions, and be used to characterize wine terroirs for forensic purpose. 


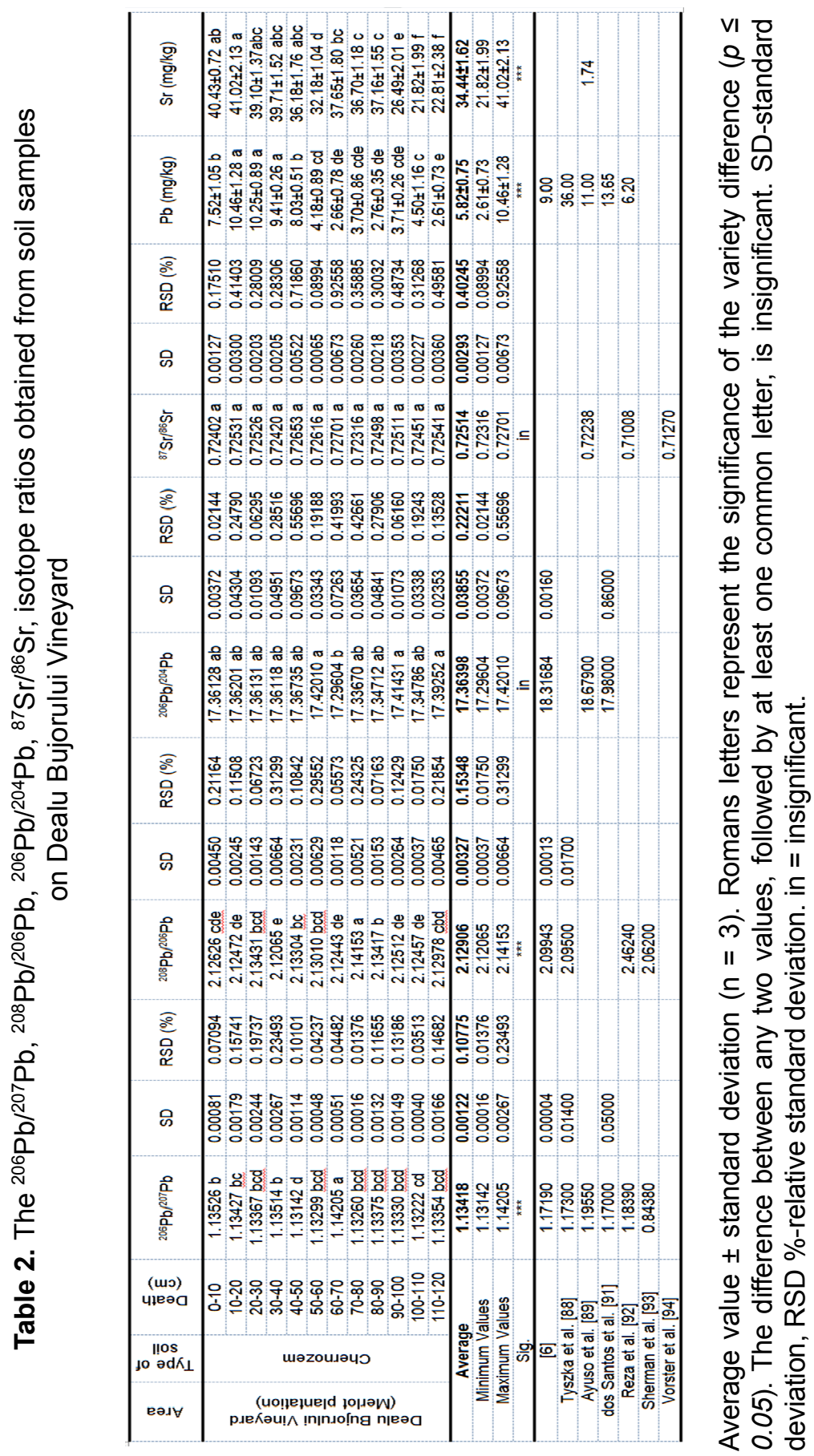




\section{EXPERIMENTAL SECTION}

\section{Study area}

Soil samples was harvested from Dealu Bujorului vineyard $\left(45^{\circ} 52^{\prime} 10^{\prime \prime} \mathrm{N}, 27^{\circ} 55^{\prime} 8\right.$ "E), the scattered spreading territory of this vineyard corresponds almost entirely to the geographical subunit known as Colinele Covurluiului, in whose area is also the Dealu Bujorului vineyard. The vineyard is crossed by the parallel $46^{\circ}$ latitude north, intersected by the $28^{\circ}$ longitude meridian. Dealu Bujorului vineyard belongs to Galați country. The specificity of the transition area is highlighted by the predominance of deposits of clays and sands. Versants were made from clay deposits and sandy sands.

\section{Soil sample collection}

Soil sampling was carried out on the depth of the soil profile $(0-10$ $\mathrm{cm}, 10-20 \mathrm{~cm}, 20-30 \mathrm{~cm}, 30-40 \mathrm{~cm}, 40-50 \mathrm{~cm}, 50-60 \mathrm{~cm}, 60-70 \mathrm{~cm}, 70-80$ $\mathrm{cm}, 80-90 \mathrm{~cm}, 90-100 \mathrm{~cm}, 100-110 \mathrm{~cm}$ and $110-120 \mathrm{~cm})$. Soil samples were collected using stainless steel shovels and were stored in individual black plastic bags (darkness). All samples were taken in triplicates from the defined experimental plot. Soil samples have been brought first to sand-size material ( $<2 \mathrm{~mm}$ ) using a jaw crusher then mechanically split to obtain a representative samples and eventually pulverized to powder-size, grain-size smaller than $100 \mu(<400$ mesh), using a ball mill. Agate ball mill is used in place of any other pulverization metal device to avoid possible trace element contamination [54]. Soil samples before splitting and pulverisation have been dried at $60{ }^{\circ} \mathrm{C}$.

\section{Reagents and solutions}

Ten elements ( $\mathrm{Cd}, \mathrm{Pb}, \mathrm{U}, \mathrm{Hg}, \mathrm{As}, \mathrm{Sr}, \mathrm{Co}, \mathrm{Cu}, \mathrm{Ni}$ and $\mathrm{Cr}$ ) were determined in order to assess their ability to discriminate wines by geographical origin. The analysis was made using multielement analysis and ICP-MS technique, after an appropriate dilution, using external standard calibration method. The calibration was performed using XXICertiPUR multielement standard, and from individual standard solution of $\mathrm{Cr}$ and $\mathrm{Hg}$. The working standards and the control sample were prepared daily from the intermediate standards that were prepared from the stock solution. The intermediate solutions stored in polyethylene bottles and glassware was cleaned by soaking in $10 \% \mathrm{v} / \mathrm{v} \mathrm{HNO}_{3}$ for 24 hours and rinsing at least ten rimes with ultrapure water $\left(18.2 \mathrm{M} \Omega \mathrm{cm}^{-1}\right.$ ultrapure water-Types 1$)$. The 
accuracy of the methods was evaluated by replicate analyses of fortified samples $(10 \mu \mathrm{L}-10 \mathrm{~mL}$ concentrations) and the obtained values ranged between 0.8-13.1 percent, depending on the element. The global recovery for each element was estimated and the obtained values were between 84.6$100.9 \%$ [21].

For quality control purpose, blanks and triplicates samples $(n=3)$ were analyzed during the procedure. The variation coefficient was under $5 \%$ and detection limits (ppb) were determined by the calibration curve method. Limit of detection (LoD) and Limit of quantification (LoQ) limits were calculated according to the next mathematical formulas: $\mathrm{LoD}=3 \mathrm{SD} / \mathrm{s}$ and $\mathrm{LoQ}=10 \mathrm{SD} / \mathrm{s}$ (SD = estimation of the standard deviation of the regression line; $s=$ slope of the calibration curve).

Table 3. Instrumental conditions for the determination of each element (ICP-MS technique)

\begin{tabular}{|c|c|c|c|c|}
\hline Element & $\begin{array}{c}\text { Correlation } \\
\text { coefficient }\end{array}$ & $\begin{array}{c}\mathrm{LoD}^{*} \\
(\mu \mathrm{g} / \mathrm{L})\end{array}$ & $\begin{array}{c}\mathrm{LoQ}^{* * *} \\
(\mu \mathrm{g} / \mathrm{L})\end{array}$ & $\begin{array}{c}\mathrm{BEC}^{* *} \\
(\mu \mathrm{g} / \mathrm{L})\end{array}$ \\
\hline $\mathrm{Cd}$ & 0.9999 & 0.0202 & 0.0673 & 0.027 \\
\hline $\mathrm{U}$ & 0.9999 & 0.0253 & 0.0842 & 0.005 \\
\hline $\mathrm{As}$ & 0.9999 & 0.2335 & 0.7776 & 0.538 \\
\hline $\mathrm{Co}$ & 0.9999 & 0.0365 & 0.1215 & 0.152 \\
\hline $\mathrm{Ni}$ & 0.9999 & 0.0591 & 0.1968 & 0.091 \\
\hline $\mathrm{Pb}$ & 0.9999 & 0.0003 & 0.0010 & 0.002 \\
\hline $\mathrm{Hg}$ & 0.9999 & 0.0417 & 0.1379 & 0.128 \\
\hline $\mathrm{Sr}$ & 0.9999 & 0.1434 & 0.4775 & 0.955 \\
\hline $\mathrm{Cu}$ & 0.9999 & 0.0402 & 0.1339 & 0.237 \\
\hline $\mathrm{Cr}$ & 0.9999 & 1.6630 & 5.5378 & 0.636 \\
\hline
\end{tabular}

*Detection limit; **Background equivalent concentration; ${ }^{* * *}$ Quantification limit.

For calibration and also to verify the achieved accuracy and precision, ten NIST-SRM 987 and NIST-SRM 982 analysis results were pooled together with the calculated relative standard deviation presented in Table 4. Based on the obtained results, it was verified that, applying quadrupole ICP-MS, relative standard deviation and reproducibility of approximately $0.5 \%$ for ${ }^{87} \mathrm{Sr} /{ }^{86} \mathrm{Sr},{ }^{206} \mathrm{~Pb} /{ }^{207} \mathrm{~Pb}$ and ${ }^{208} \mathrm{~Pb} / 206 \mathrm{~Pb}$ are feasible. The results were in agreement with those reported by $[21,52]$. 
Table 4. Lead isotopic ration and Lead isotopic ration determination precision and accuracy based on the NIST SRM 982 (Lead) NIST SRM 987 (Strontium) $(n=10)$

\begin{tabular}{|c|c|c|c|c|c|c|c|c|}
\hline Replicate & $\begin{array}{c}{ }^{207} \mathrm{~Pb} /{ }^{206} \mathrm{~Pb} \\
(\mathrm{a})\end{array}$ & $\begin{array}{c}\mathrm{RSD} \\
(\%)\end{array}$ & $\begin{array}{c}{ }^{208} \mathrm{~Pb} /{ }^{206} \mathrm{~Pb} \\
(\mathrm{~b})\end{array}$ & $\begin{array}{c}\mathrm{RSD} \\
(\%)\end{array}$ & $\begin{array}{c}{ }^{204} \mathrm{~Pb} /{ }^{206} \mathrm{~Pb} \\
(\mathrm{c})\end{array}$ & $\begin{array}{c}\mathrm{RSD} \\
(\%)\end{array}$ & $\begin{array}{c}{ }^{77} \mathrm{Sr} /{ }^{86} \mathrm{Sr} \\
(\mathrm{d})\end{array}$ & $\begin{array}{c}\mathrm{RSD} \\
(\%)\end{array}$ \\
\hline 1 & 0.46483 & 0.51 & 0.99891 & 0.67 & 0.00271 & 0.32 & 0.70493 & 0.31 \\
\hline 2 & 0.47891 & 0.48 & 0.99452 & 0.61 & 0.00272 & 0.41 & 0.72046 & 0.45 \\
\hline 3 & 0.46978 & 0.32 & 0.99794 & 0.55 & 0.00275 & 0.28 & 0.70325 & 0.63 \\
\hline 4 & 0.47123 & 0.64 & 0.99688 & 0.64 & 0.00273 & 0.51 & 0.70634 & 0.48 \\
\hline 5 & 0.46987 & 0.56 & 0.99726 & 0.48 & 0.00246 & 0.14 & 0.71478 & 0.36 \\
\hline 6 & 0.46154 & 0.37 & 0.99647 & 0.56 & 0.00258 & 0.39 & 0.71245 & 0.59 \\
\hline 7 & 0.47362 & 0.70 & 0.99969 & 0.34 & 0.00279 & 0.47 & 0.70987 & 0.46 \\
\hline 8 & 0.45641 & 0.43 & 0.99744 & 0.58 & 0.00278 & 0.51 & 0.72326 & 0.42 \\
\hline 9 & 0.41562 & 0.36 & 0.99576 & 0.59 & 0.00273 & 0.49 & 0.70845 & 0.68 \\
\hline 10 & 0.45612 & 0.45 & 0.99874 & 0.61 & 0.00278 & 0.36 & 0.10789 & 0.47 \\
\hline Average & 0.46179 & 0.48 & 0.99736 & 0.56 & 0.00270 & 0.41 & 0.71117 & 0.49 \\
\hline
\end{tabular}

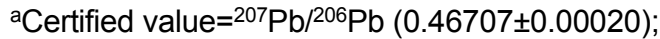

${ }^{b}$ Certified value $=208 \mathrm{~Pb} / 206 \mathrm{~Pb}(1.00016 \pm 0.00036)$;

${ }^{\mathrm{c} C e r t i f i e d ~ v a l u e}={ }^{204} \mathrm{~Pb} /{ }^{206} \mathrm{~Pb}(0.027219 \pm 0.00027)$;

${ }^{\mathrm{d}}$ Certified value $={ }^{87} \mathrm{Sr} /{ }^{86} \mathrm{Sr}(0.71034 \pm 0.00026) ; \mathrm{RSD}(\%)=$ relative standard deviation.

\section{Sample preparation for determination of heavy metals and isotopic ration from soil using ICP-MS}

For the determination of heavy metals from soils samples were used an amount of $0.5 \mathrm{~g}$ soil and adjust $8 \mathrm{~mL}\left(7 \mathrm{~mL} \mathrm{HNO} 365 \%+1 \mathrm{~mL} \mathrm{H}_{2} \mathrm{O}_{2}\right)$ were placed in a clean Teflon digestion vessel, after 15-30 minutes the mineralization was performed using a microwave system Milestone START D Microwave Digestion System set in three steps: step I (time $10 \mathrm{~min}$, temperature $220^{\circ} \mathrm{C}$ ), step II (time $15 \mathrm{~min}$., temperature $220^{\circ} \mathrm{C}$ ) and step III (time 60 min., ventilation - temperature $35^{\circ} \mathrm{C}$ ). After mineralization, samples were filtered through a $0.45 \mathrm{~mm}$ filter and brought to a volume of $50 \mathrm{~mL}$. The $\mathrm{Pb}$ and $\mathrm{Sr}$ isotope ration in the analysed soil samples $\left({ }^{206} \mathrm{~Pb} /{ }^{207} \mathrm{~Pb}\right.$, ${ }^{208} \mathrm{~Pb} /{ }^{206} \mathrm{~Pb},{ }^{206} \mathrm{~Pb} /{ }^{204} \mathrm{~Pb},{ }^{87} \mathrm{Sr} /{ }^{86} \mathrm{Sr}$,) were determined according to the methodology indicated by Mihaljevič et al. [51]; Geana et al. [21].

In order to confirm the best chosen conditions for soil digestion standard additions for checking accuracy of the microwave digestion and recoveries were calculated (Table 5). The digestion seemed visually completed in all of the combinations, but the spiked recoveries showed significant differences for total elements content $(p=0.005)$. 
Table 5. Standard additions for checking accuracy of the microwave digestion ICP-MS method $(n=3)$

\begin{tabular}{|c|c|c|}
\hline Element & $\begin{array}{c}\text { Certified Concentration } \\
(\mathrm{mg} / \mathrm{kg})\end{array}$ & $\begin{array}{c}\text { Measured Concentration } \\
(\mathrm{mg} / \mathrm{kg})\end{array}$ \\
\hline $\mathrm{Cd}$ & $0.371 \pm 0.002$ & $0.369 \pm 0.006$ \\
\hline $\mathrm{U}$ & $3.15 \pm 0.05$ & $3.17 \pm 0.03$ \\
\hline $\mathrm{As}$ & $10.50 \pm 0.30$ & $10.26 \pm 0.18$ \\
\hline $\mathrm{Co}$ & $130.00 \pm 9.00$ & $129.32 \pm 0.36$ \\
\hline $\mathrm{Ni}$ & $85.00 \pm 2.00$ & $83.65 \pm 1.89$ \\
\hline $\mathrm{Pb}$ & $0.00173 \pm 0.00001$ & $0.00169 \pm 0.0002$ \\
\hline $\mathrm{Hg}$ & $0.90 \pm 0.20$ & $0.91 \pm 0.21$ \\
\hline $\mathrm{Sr}$ & $239.00 \pm 6.00$ & $238.02 \pm 1.56$ \\
\hline $\mathrm{Cu}$ & $33.90 \pm 0.50$ & $33.96 \pm 0.53$ \\
\hline $\mathrm{Cr}$ & $130.00 \pm 9.00$ & $130.15 \pm 0.78$ \\
\hline
\end{tabular}

\section{Instrumentation}

The determination of metals was performed on mass spectrometer with inductively coupled plasma, (ICP-MS) iCAP Q Thermo scientific model, based polyatomic species before they reach the quadrupole mass spectrometer, using a PFA micro flow concentric nebulizer. The argon used was of $99.99 \%$ purity (Messer, Austria). The instrument was daily optimized to give maximum sensitivity for $\mathrm{M}^{+}$ions and the double ionization and oxides monitored by the means of the rations between $\mathrm{Ba}^{2+} / \mathrm{Ba}^{+}$and $\mathrm{Ce}^{2+} / \mathrm{CeO}^{+}$, respectively, these always being less than $2 \%$. The experimental conditions were: argon flow on nebulizer $(0.82 \mathrm{~L} / \mathrm{min}$.), auxiliary gas flow $0.80 \mathrm{~L} / \mathrm{min}$., argon flow in plasma $15 \mathrm{~L} / \mathrm{min}$., lens voltage $7.30 \mathrm{~V}$; RF power in plasma $1100 \mathrm{~W}$, spray chamber temperature $\left(2.50 \pm 1.00^{\circ} \mathrm{C}\right)$. Accuracy was calculated for the elements taken into consideration (0.5-5.0\%).

\section{Statistical analysis}

The statistical interpretation of the results was performed using the Duncan test, SPSS Version 24 (SPSS Inc., Chicago, IL., USA). The statistical processing of the results was primarily performed in order to calculate the following statistical parameters: average and standard deviation. This data was interpreted with the analysis of variance (ANOVA) and the average separation was performed with the DUNCAN test at $p \leq 0.05$. 


\section{ACKNOWLEDGMENTS}

This paper was published under the frame of the Romanian Ministry of Agriculture and Rural Development, project ADER no. 14.2.2. "Quantitative studies on assessment and monitoring contaminants, on the chain of viticulture and winemaking to minimize the amount of pesticides and heavy metals as principal pollutants".

\section{REFERENCES}

1. Li, J.L., He, M., Han, W., Gu, Y.F., Journal of Hazardous Materials, 2009, 164, 976-981.

2. L.R.F. Alleoni, R.B. Borba, O.A. Camargo, Topicos em Ciencia do Solo, 2005, 4, 1-42.

3. J.F.G.P. Ramalho, N.M.B. Amaral Sobrinho, A.C.X. Velloso, Pesquisa Agropecuaria Brasileira, 2000, 35, 1289-1303.

4. A. Kabata-Pendias, "Trace elements in soils and plants". 4th ed. Boca Raton: Chemical Rubber Company Press, 2011.

5. A. Facchinelli, E. Sacchi, L. Mallen, Environmental Pollution, 2001, 114 (3), 313-324.

6. M.C. Ramos, M. L'opez-Acevedo, Advances in Environmental Research, 2004, 8 (3-4), 687-696.

7. M. Kom'arek, E. 'Cadkov'a, V. Chrastn'y, F. Bordas, J. Bollinger, Environment International, 2010, 36 (1), 138-151.

8. G.C.G. dos Santos, G.S. Valladares, C.A. Abreu, O.A. de Camargo, C.R. Grego, Applied and Environmental Soil Science, 2013, Article ID790795, 1-10.

9. W. Preston, Y.J.A.B. da Silva, C.W.A. do Nascimento, K.P.V. da Cuhna, D.J. Silva, H.A. Ferreira, Geoderma Regional, 2016, 7, 357-365.

10. C. Nicula, A. Peter, L. Mihaly-Cozmuta, A. Mihaly-Cozmuta, Carpathian Journal of Food Science and Technology, 2013, 5 (1-2), 1-8.

11. G.R. Nachtigall, R.C. Nogueirol, L.R.F. Alleoni, M.A. Cambri, Brazilian Archives of Biology and Technology, 2007, 50 (6), 941-948.

12. Q-Y. Wanga, D-M. Zhoua, L. Canga, Soil Biology and Biochemistry, 2009, 41, 1504-1509.

13. L. Bretan, O. Ketney, F. Boltea, Carpathian Journal of Food Science and Technology, 2010, 2 (2), 8-12.

14. A. Kabata-Pendias, H. Kabata, "Trace elements in soils and plants", 3rd edition CRC Press, Boca Raton, 2001.

15. V. Antoniadis, C.D. Tsadilas, Applied Geochemistry, 2007, 22, 2375-2380.

16. E.V. Mellis, M.P. Cruz, J.C. Casagrande, Scientia Agricola, 2004, 61 (2), 190195. 
DETERMINATION OF HEAVY METALS AND LEAD-STRONTIUM ISOTOPE CHARACTERIZATION ...

17. M. Senila, T. Kotsev, E. Levei, M. Roman, V. Mladenov, Z. Cholakova, L. Senila, STUDIA UBB CHEMIA LXI, 2016, 3, Tom II, 333-344.

18. S. Kelly, K. Heaton, J. Hoogewerff, Trends in Science and Technology, 2005, 16, 555-567.

19. M. Berglund, M.E. Wieser, Pure and Applied Chemistry, 2011, 83 (2), 397410.

20. P. Martins, M. Madeira, F. Monteiro, OIV, 2013, 48 (1), 21-29.

21. E.I. Geana, A. Marinescu, A.M. Iordache, C. Sandru, R.E. Ionete, C. Bala, Food Analytical Methods, 2017, 10 (1), 63-73.

22. K.J.R. Rossman, P. D. P. Taylor, International Union of Pure and Applied Chemistry, 1998, 70 (1), 217-235.

23. H. Cheng, Y. Hu, Environmental Pollution, 2010, 158 (5), 1134-1146.

24. W.U. Ault, R.G. Senechal, W.E. Erlebach, Environmental Science and Technology, 1970, 4, 305-313.

25. S. Marchionni, A. Buccianti, A. Bollati, Food Chemistry, 2016, 190, 777-785.

26. R.D. Di Paola-Naranjo, M. V. Baroni, N. S. Podio, Journal of Agricultural and Food Chemistry, 2011, 59, 7854-7865.

27. M.R. Mercurio, E. Grilli, P. Odierna, V. Morra, T. Prohaska, E. Coppola, C. Grifa, A. Buondonno, A. Langella, Geoderma, 2014, 230-231, 64-78.

28. C. Baschieri, L. Bertacchini, D. Bertelli, M. Cocchi, A. Marchetti, D. Manzini, G. Papotti, S. Sighinolfi, Food Chemistry, 2015, 173, 557-563.

29. S. Voerkelius, G.D. Lorenz, S. Rummel, C.R. Quéte, G. Heiss, M. Baxter, C. Brach-Papa, P. Deters-Itzelberger, S. Hoelzl, J. Hoogewerff, E. Ponzevera, M. van Bocxstaele, H. Ueckermann, Food Chemistry, 2010, 118, 933-940.

30. E. Mahmoudabadi, F. Sarmadian, R.N. Moghaddam, International Journal of Environmental and Science Technology, 2015, 12 (10), 3283-3298.

31. F. Curran-Cournane, G. Lear, L. Schwendenmann, J. Khin, Soil Research, 2015, 53, 306-315.

32. S.Č. Alagić, D.B. Tošić, M.D. Dimitrijević, M.A. Antonijevic, M.M. Nujikic, Environmental Science and Pollution Research, 2014, 22 (9), 7155-7175.

33. C. Moragues-Quiroga, J. Juilleret, L. Gourdol, E. Pelt, T. Perrone, A. Aubert, G. Morvan, F. Chabaux, A. Legout, P. Stille, C. Hissler, Catena, 2017, 149 (1), 185-198.

34. A. Saat, A.S. Kamsani, W.N.A.N. Kamri, N.H.M. Talib, A.K. Wood, Z. Hamzah, AIP Conference Proceeding, 2015, 1659 (1), 1-6.

35. H. Kailing, S. Zehanf, H. Yuanan Z. Xiangying; Y., Zhiqiang; C., Hefa, Environmental Science and Pollution Research, 2017, 24, 9387-9398.

36. M. Laghlimi, European Journal of Scientific Research, 2015, 129 (2), 167-178.

37. R.T. Ottesen, M. Birke, T.E. Finne, et al., Applied Geochemistry, 2013, 33, 1-12.

38. M. Çolak, Journal of Environment and Earth Science, 2012, 67, 695-712.

39. M. Mirlean, A. Roisenberg, J.O. Chies, Environmental Pollution, 2007, 149, 10-17.

40. L.M. Flores-Veles, J. Ducaroir, A. M. Jaunet, M. Robert, European Journal of Soil Science, 1996, 47, 523-532. 
41. F. Pinamonti, G. Nicolini, A. Dalpiaz, et al., Communications in Soil Science and Plant Analysis, 1999, 30, 1531-1549.

42. F.D. Bora, C.I. Bunea, T. Rusu, et al., Chemistry Central, 2015, 9, 1-13.

43. E.I.B. Chopin, B. Marin, R. Mkougafoko, et al., Envrionmental Pollution, 2008, 156, 1092-1098.

44. S. Bravo, J.A. Amorós, C. Pérez-de-los-Reyes, et al., Journal of Geochemical Exploration, 2015, 173, 79-83.

45. R.R. Couto, L. Benedet, J.J. Comin, et al., Environmental Earth Sciences, 2014, 73 (10), 6379-6386.

46. M. Romić, D. Romić, G. Ondrašek, Agriculturae Conspectus Scientificus, 2004, 2-3, 35-41.

47. V. Chaignon, I. Sanchez-Neira, P. Herrmann, et al., Environmental Pollution, 2003, 123, 229-238.

48. D. Rusjan, M. Strlič, D. Pucko, et al., Geoderma, 2006, 136, 930-936.

49. I. Galušková, M. Mihaljevič, L. Borůvka, et al., Journal of Geochemical Exploration, 2014, 147, 215-221.

50. M. Komárek, V. Ettler, V. Chrastny, et al., Environmental International, 2008, 34, 562-577.

51. M. Mihaljevič, V. Ettler, O. Šebek, et al., Journal of Geochemical Exploration, 2006, 88, 130-133.

52. C.M.S. Almeida, A.C. Almeida, M.L.D.P. Godoy, et al., Journal of the Brazilian Chemical Society, 2016, 27 (6), 1-6.

53. T. Drouet, J. Herbauts, W. Gruber et al., European Journal of Soil Science, 2007, 58, 302-319.

54. A. Takamasa, S. Nakai, Geochemical Journal, 2009, 43, 389-394. 